\title{
SURVEY Study ON SOME ARTIFICIAL COLORS \\ INTAKE BY CHILDREN IN DAMIETTA
}

\author{
By \\ Emara; H.M. EL-seedy,G.M.; Shohieb ,M.A. \\ Fac. of Specific Education, Damietta Univ.
}

\section{Research gournal Specific Fducation}

Faculty of Specific Education

gYansoura University

ISSUE NO. 60, OCTOBER , 2020

مجلة بحوث التربية النوعية - جامعة المنصورة

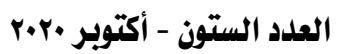




\section{SURVEY StUdY ON SOME ARTIFICIAL COLORS}

INTAKE BY GHILOREN IN DAMIETTA

\section{Emara; H.M. EL-seedy ,G.M.; Shohieb ,M.A. *}

\section{Abstract}

Food is essential for the proper growth and development of children, and excessive consumption of artificial colors in baby foods is a serious health problem that has a negative impact on the growth and health of children.

The aim of this study was to evaluate a survey of artificial colors in children's foods in Damietta governorate in children aged between 1 and 7 years and its impact on the child's general health, especially anemia in children.

The study included 200 children from nurseries and primary schools in Damietta Governorate, and we conducted a survey of children's sweets in the supermarket to determine the industrial colors, especially the industrial color of tartrazine( E102 ) and the industrial color of carmoisine (E122). Baby foods such as jelly, soft drinks, Lolita and Children's Candy. We analyzed the concentrations of the synthetic colorant tatrazine (E102) and the synthetic colorant carmosine (E122) in baby foods in ( HPLC) Chromatograph.

We analyzed anemia before giving the children the artificial colors in the baby sweets. Then we analyzed after giving the children sweets containing the artificial colors.

The results showed that children at the age of three years ate more children's foods containing artificial colors the most consumed of food for children by a percentage of $(56.71 \%)$ and then the percentage started to decline for the following are age groups.

\footnotetext{
*Fac. of Specific Education, Damietta Univ.
} 
The percentage of consumption of baby food in the second year of the age stage is (33.\% ) and the percentage of consumption of baby food in the fourth year of the child's life stage is $(12.95 \%)$ )As for the percentage of consumption of baby food in the fifth year of the child's life stage, (4.85\%) and the consumption rate in the seventh year of the child's age stage is (12.91\%). The results showed that the percentage of the intake of children's sweets in different samples of tartarazine (102) that were analyzed on the HpLC device was less than the international permissible, as it was found that the percentage of $100 \mathrm{mg}$ of Lolita, the percentage of fortification in it of the substance of tatarazine is about 33.59 micrograms and the percentage

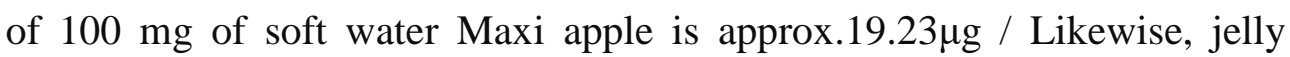
straw jelly, the concentration ratio is about $14.71 \mathrm{mg}$, the concentration ratio in UGO carbonated water is $13.21 \mu \mathrm{g}$, and the concentration ratio in Orange jelly is $17.02 \mathrm{mg}$. it becomes clear that the average concentration of tartarzine (E 102) in the foods that the children ate (the research sample) was less than the international permissible $(7.5 \mathrm{mg}$ per kilogram of the human body) .

The results of carmosine showed that it is less than the permissible limits

it becomes clear that the average concentration of carmosine (E 122) in the foods that the children ate (the research sample) was less than the international permissible (4 milligrams per kilogram of the human body).

The results showed That there was a significant effect of the number of intake times on hemoglobin Levels after eating children's food, where the value of "P"< (28.31\%)and The level of significance reached $(0.0001)$ Indicating the presence of statistically significant differences between the number Of intake and this led to a high rate of anemia among children the research sample after eating children's food

However, previous research is still proving that tartrazine is a toxic pigment, and in this study we showed not a harmful effect of tartrazine and 
carmosine on children's anemia, and it was measured by doing an anemia test for children, and the results confirm that.

Keywords: artificial colors; tartrazine; Carmoisine; anemia .

\section{INTRODUCTION}

The color plays a significant role in acceptability of food stuffs, but unfortunately not all coloring agents are harmless. However, there was an increase in the use of toxic synthetic colorants over the last 30 years (Sawaya et al., 2008).

In Egypt, there has been a sharp increase in the use of synthetic food colorants in the past few years (Amin et al., 2010; El-Sheikh; Al-Degs, 2013).

Food colorants (dyes) play vital role in the selection of food. They are used in food to improve appearance, enhance attraction, prevent loss of color when processing or storing foods, and stimulates psychological satisfaction (Amin et al., 2010).

Food additives are substances added to food in order to retain or improve desirable characteristics or quality. In the last years many more additives have been introduced, of either natural or artificial origin. Many of which can be the cause of certain health conditions, such as E102 that can cause. Asthma attacks and has links to thyroid tumors, 122 can cause bad reactions in asthmatics and people allergic to aspirin (Martin, 2007).

Shafiquzzaman and Shaarani, (2016) reported that food dyes can be categorized into natural and synthetic color. Tartrazine (E102) which belong to the family of azo dyes and commonly used in food industry. Tartrazine imparts positive and negative benefits as well, by giving attractive physical appearance and consumer acceptance for over centuries. However, excessively intake of food Tartrazine can cause toxicity and pathogenicity to human. Latifa et al., (2017) showed that the current study aimed to evaluate the possible adverse effect of this coloring food additive on renal and hepatic structures and functions. Also, the genotoxic, the results showed that tartrazine intake may lead to adverse health effects. Kamal and Fawzia ,(2018) showed that Non-food products: Tartrazine 
may be found in non-food products like soaps, cosmetics, shampoos and other hair products, conditioners, pastels, crayons and stamp dyes. Medications: particular medical preparations comprise tartrazine as antiacids, vitamins, certain prescription medications and medical capsules. Accruing research has been performed on tartrazine and its effect on the health.

(Yamjala et al.,2016) carmoisine as an improvement and attractive agent for clientage by making visually aesthetic or to reinstate the original appearance. ( Salama et al.,2016) In recent years, food additives in general, and colors, in particular, have increasingly come under investigation for the evaluation of their safety in use .

\section{Materials and Methods}

This study was conducted on children of nurseries and primary schools, especially the first and second primary grades, and their ages ranged between 1-7 years, and this study began in August 2015 and ended in May 2021, and the target group was children from the age of 1 to 7 years in nurseries and primary schools in Damietta governorate.

\section{1- A questionnaire about artificial color}

This questionnaire in includes the period of artificial color In foods includes the nutritional history from the age of 1year to 7years and the number of times this food contains artificial colors monthly, weekly and daily

And the number of daily eating times one or more times ,twice or more , three times and more as well as weekly and monthly, and never at all the purpose the questionnaire was to evaluate the indicator of the intake of artificial colors in baby (appendix 1)

\section{2- Weight}

Weight /age were recorded using abeam scale. Subjects were weighted To the nearest kilogram without shoes and in light clothes. The scale was calibrated before use. (Jelliffe, 1966) 


\section{3- Determination of food colorants using HPLC}

Synthetic dyes of E 102 and E 122 were determined according to the method described by (Laurian et al., 2014) as follows: Synthetic dyes stock solutions were prepared in methanol at the concentrations of $1 \mathrm{mg} / \mathrm{ml}$. While, working solutions were prepared by diluting specific volumes of stock solution with distilled water, yielding six standards with concentration ranged between 100 and $10000 \mathrm{ng} / \mathrm{ml}$.

Jelly ( $2 \mathrm{~g}$ ) was extracted using $20 \mathrm{ml}$ methanol for 15 min under continuous stirring. Moreover, the obtained extract and other samples were degassed for $2 \mathrm{~min}$ in the ultrasonic bath, followed by filtration using syringe filter $(0.22 \mu \mathrm{m})$. Then, the filtrate was diluted for specific volumes using distilled water.

The HPLC system (Jasco, Japan) with an UV detector was used for dye determination. For the separation, a reversed phase Agilent SB C18 analytical column, $250 \times 4.5 \mathrm{~mm}, 5 \mu \mathrm{m}$ particles was used (Agilent Technologies, $\boldsymbol{U S A}$ ) at $45^{\circ} \mathrm{C}$. The mobile phase consists in a mixture The HPLC system (Jasco, Japan) with an UV detector was used for dye determination. For the separation, a reversed phase Agilent SB C18 analytical column, $250 \times 4.5 \mathrm{~mm}, 5 \mu \mathrm{m}$ particles was used (Agilent Technologies, $\boldsymbol{U S A})$ at $45^{\circ} \mathrm{C}$. The mobile phase consists in a mixture of 100 $\mathrm{mM}$ ammonium acetate (A)/acetonitrile (B) gradient elution (beginning with $4 \% \mathrm{~B}$, until $7 \mathrm{~min} 35 \% \mathrm{~B}$, to $7.2 \mathrm{~min} 35 \% \mathrm{~B}$, until $7.21 \mathrm{~min} 4 \% \mathrm{~B}$ ). The flow rate was $1 \mathrm{~mL} / \mathrm{min}$ with injection volume of $20 \mu \mathrm{L}$. Additionally, E 102 and $\mathrm{E} 122$ dyes were read at 420 and $520 \mathrm{~nm}$, respectively

\section{4- Chemical analysis hemoglobin of children:}

Blood samples were taken from children from Kindergartens and primary schools in Damietta governorate 200samples from children 1to7 years old and the hemoglobin

Level was analyzed before eating (sweet children)foods added to it the industrial coloring(containing artificial colors, tartazine and carmoisine) and the proportion of hemoglobin after eating was analyzed the work of 
analysis of the hemoglobin ( $\mathrm{Hb}$ ) described according to method (Lee and Nieman, 1996).

\section{Results and Discussion}

\section{Food history}

Data in table (1) and fig (1) showed that relative distribution of children in the research in items of consumption of baby (children) food according to the age group. Those children at the age of three years where it was found are the most consumed of food for children by percentage of $56.71 \%$ and then the percentage started to decline for the following age groups. The percentage of consumption of baby food in the second year of the age stage is $33 . \%$ and the percentage of consumption of baby food in the fourth year of the child's life stage is $12.95 \%$ As for the percentage of consumption of baby food in the fifth year of the child's life stage, $12.95 \%$, and this percentage is repeated As for the percentage of consumption of baby food in the sixth year of the child's age stage, $4.85 \%$, and the consumption rate in the seventh year of the child's age stage is $12.91 \%$ Elena, (2013) reported that rapid growth and development occurs during the preschool years, ages 2 through 5. A child grows about 2 to 3 inches. Proper nutrition and opportunities to play and be physically active are critical to ensuring your child grows properly, learns to enjoy nutritious foods, and adopts healthy behaviors for maximum development and lifelong health.

Table (1): Relative distribution of children in the research in terms of consumption of baby (children) food according to the age group.

\begin{tabular}{|c|c|c|}
\hline Child age & $\%$ & Ranked \\
\hline \hline Year & - & - \\
\hline 2 years & $0.33 \%$ & 6 \\
\hline 3 years & $56.71 \%$ & 1 \\
\hline 4 years & $12.95 \%$ & 2 \\
\hline 5 years & $12.95 \%$ & 2 Rep. \\
\hline 6 years & $4.85 \%$ & 5 \\
\hline 7 years & $12.91 \%$ & 4 \\
\hline
\end{tabular}




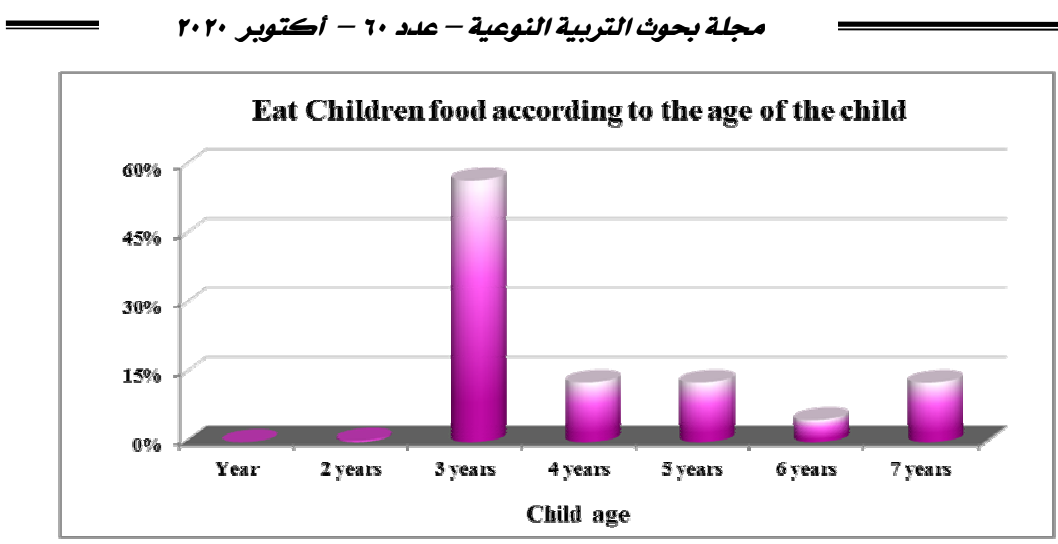

Fig (1) Relative distribution of children in the research, in terms of the consumption of baby (children)food according to age group.

Data in table (2) shown that and Fig( 2 ) relative distribution of children in the research sample in terms of the number of baking meals . The cultivar TETE came stuffed with cream and Jelly with the flavor of Strawberries most eaten daily by (79.5\%). Followed by HOHOS by (69.5\%).

Then come TETE with cream and lemon flavor by $(66.9 \%)$ and orange by $(66.5 \%)$. The HOHOS Chocolate cake by $(63.2 \%)$ and then the rest of the baked goods come according the percentage Fig (2) illustrates

In terms of the number of times you eat baked foods daily, more than once a day and a week, more than once a week, monthly and absolutely.

These results are in agreement with those reported by Batada and Jacobson., (2016) showed that artificial food colors (AFCs) in foods and beverages may be harmful to children. This study assesses the percentage of grocery store products marketed to children that contain AFCs, by category and company. -. (43.2\%contained AFCs. The most common AFCs were Red 40 (29.8\% of products), Blue 1 (24.2\%), Yellow 5 (20.5\%), and Yellow $6(19.5 \%)$. Produce was the only category that did not have any AFCs. The highest percentage of products with AFCs was found in candies (96.3\%), fruit-flavored snacks (94\%), and drink mixes/powders (89.7\%). Forty-one of the 66 companies marketed products containing AFCs. Given concerns about health effects of AFCs and high proportions of high-AFC categories, 


\section{= Survey Study On some Artificial Colors Intake by Children in Damietta}

clinicians, parents, food companies, and the government can take steps to support children's healthy eating and development by reducing AFCs in children's diets.

Table (2 ): Relative distribution of children in the research sample in terms of the number of baking meals .

\begin{tabular}{|c|c|c|c|c|c|c|c|c|c|c|c|c|c|c|c|}
\hline \multirow{3}{*}{ 产 } & \multirow{3}{*}{ Item } & \multicolumn{12}{|c|}{ Eating children's foods } & \multirow{3}{*}{ 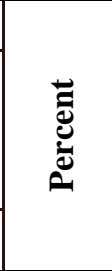 } & \multirow{3}{*}{ 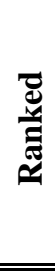 } \\
\hline & & \multicolumn{2}{|c|}{ Daily } & \multicolumn{2}{|c|}{$\begin{array}{l}\text { More than } \\
\text { once a day }\end{array}$} & \multicolumn{2}{|c|}{ Weekly } & \multicolumn{2}{|c|}{$\begin{array}{c}\text { More than } \\
\text { once a } \\
\text { week } \\
\end{array}$} & \multicolumn{2}{|c|}{ Monthly } & \multicolumn{2}{|c|}{$\begin{array}{c}\text { I don't eat } \\
\text { at all }\end{array}$} & & \\
\hline & & Cnt & $\%$ & Cnt & $\%$ & Cnt & $\%$ & Cnt & $\%$ & Cnt & $\%$ & Cnt & $\%$ & & \\
\hline \multirow{11}{*}{ 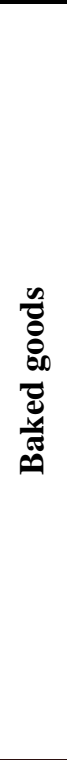 } & $\begin{array}{c}\text { TETE } \\
\text { strawberry }\end{array}$ & 128 & $64.0 \%$ & 51 & $25.5 \%$ & 3 & $1.5 \%$ & 4 & $2.0 \%$ & 10 & $5.0 \%$ & 4 & $2.0 \%$ & $79.5 \%$ & 1 \\
\hline & TETE orange & 89 & $44.5 \%$ & 37 & $18.5 \%$ & 13 & $6.5 \%$ & 25 & $12.5 \%$ & 23 & $11.5 \%$ & 13 & $6.5 \%$ & $66.5 \%$ & 4 \\
\hline & TETE Lemon & 63 & $31.5 \%$ & 45 & $22.5 \%$ & 18 & $9.0 \%$ & 46 & $23.0 \%$ & 18 & $9.0 \%$ & 10 & $5.0 \%$ & $66.9 \%$ & 3 \\
\hline & HOHOS & 101 & $50.5 \%$ & 37 & $18.5 \%$ & 16 & $8.0 \%$ & 19 & $9.5 \%$ & 17 & $8.5 \%$ & 10 & $5.0 \%$ & $69.5 \%$ & 2 \\
\hline & HOHOS COKe & 45 & $22.5 \%$ & 51 & $25.5 \%$ & 32 & $16.0 \%$ & 36 & $18.0 \%$ & 25 & $12.5 \%$ & 11 & $5.5 \%$ & $63.2 \%$ & 5 \\
\hline & F16 & 63 & $31.5 \%$ & 31 & $15.5 \%$ & 21 & $10.5 \%$ & 33 & $16.5 \%$ & 35 & $17.5 \%$ & 17 & $8.5 \%$ & $58.3 \%$ & 11 \\
\hline & $\begin{array}{c}\text { TODO } \\
\text { strawberry } \\
\end{array}$ & 66 & $33.0 \%$ & 33 & $16.5 \%$ & 26 & $13.0 \%$ & 42 & $21.0 \%$ & 17 & $8.5 \%$ & 16 & $8.0 \%$ & $62.4 \%$ & 7 \\
\hline & TODO & 75 & $37.5 \%$ & 27 & $13.5 \%$ & 31 & $15.5 \%$ & 36 & $18.0 \%$ & 26 & $13.0 \%$ & 5 & $2.5 \%$ & $63.1 \%$ & 6 \\
\hline & $\begin{array}{c}\text { PUra of } \\
\text { strawberry }\end{array}$ & 76 & $38.0 \%$ & 13 & $6.5 \%$ & 23 & $11.5 \%$ & 56 & $28.0 \%$ & 18 & $9.0 \%$ & 14 & $7.0 \%$ & $60.1 \%$ & 9 \\
\hline & TODO & 81 & $40.5 \%$ & 9 & $4.5 \%$ & 19 & $9.5 \%$ & 56 & $28.0 \%$ & 21 & $10.5 \%$ & 14 & $7.0 \%$ & $59.6 \%$ & 10 \\
\hline & $\begin{array}{c}\text { Cute taste of } \\
\text { scalp }\end{array}$ & 60 & $30.0 \%$ & 32 & $16.0 \%$ & 34 & $17.0 \%$ & 40 & $20.0 \%$ & 19 & $9.5 \%$ & 15 & $7.5 \%$ & $60.7 \%$ & 8 \\
\hline \multicolumn{3}{|c|}{ nt $(\%)$} & $\begin{array}{c}38.50 \\
\%\end{array}$ & & $\begin{array}{c}16.64 \\
\%\end{array}$ & & $\begin{array}{c}10.73 \\
\%\end{array}$ & & $\begin{array}{c}17.86 \\
\%\end{array}$ & & $\begin{array}{c}10.41 \\
\%\end{array}$ & & $5.86 \%$ & & \\
\hline
\end{tabular}




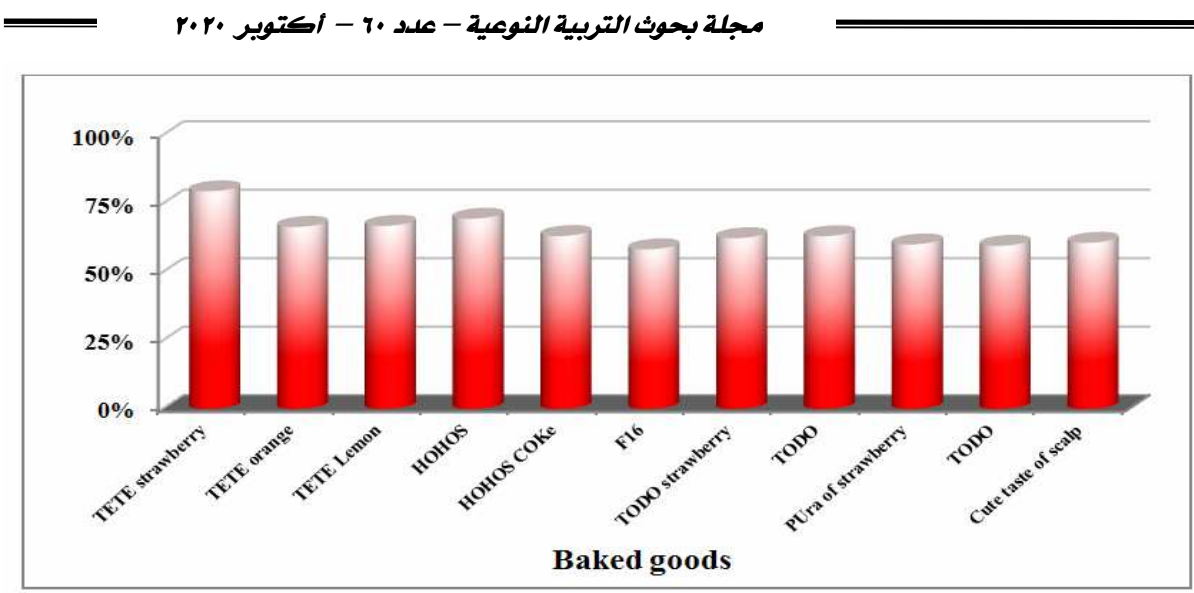

Fig (2) :Relative distribution of children in the research

Sample, in terms of the number of times to eat baked goods.

Data in table 3 and illustrated graphically in Fig (3) showed that relative distribution of children in the research sample, in terms of the number of times to eat Sweets . The item Marbella come the most eaten daily by (78.3\%) .Followed by Marbella a core by (75.6\%) Then orange lollipop by $(72 \%)$. Then come Alwan core gum by $(70.2 \%)$.and then the rest of Sweets come according to the percentage.

These results are in agreement with those reported by Ghoreishi et al.,(2012). Showed that Synthetic colorants are also widely used for coloration of food not only to improve appearance and color but also to maintain the natural color during processing or storage 
- Survey Study On some Artificial Colors Intake by Children in Damietta

Table (3) : Relative distribution of children in the research sample ,in terms of the number of times to eat sweets .

\begin{tabular}{|c|c|c|c|c|c|c|c|c|c|c|c|c|c|c|c|}
\hline \multirow{3}{*}{ 咅 } & \multirow{3}{*}{ Item } & \multicolumn{12}{|c|}{ Eating children's foods } & \multirow{3}{*}{ 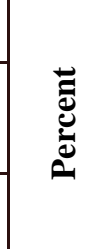 } & \multirow{3}{*}{ 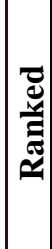 } \\
\hline & & \multicolumn{2}{|c|}{ Daily } & \multicolumn{2}{|c|}{$\begin{array}{l}\text { More than } \\
\text { once a day }\end{array}$} & \multicolumn{2}{|c|}{ Weekly } & \multicolumn{2}{|c|}{$\begin{array}{c}\text { More than } \\
\text { once a week }\end{array}$} & \multicolumn{2}{|c|}{ Monthly } & \multicolumn{2}{|c|}{\begin{tabular}{|c|}
$\begin{array}{c}\text { I don't eat } \\
\text { at all }\end{array}$ \\
\end{tabular}} & & \\
\hline & & Cnt & $\%$ & Cnt & $\%$ & Cnt & $\%$ & Cnt & $\%$ & Cnt & $\%$ & Cnt & $\%$ & & \\
\hline \multirow{16}{*}{ 㝕 } & Marbella & 49 & $24.5 \%$ & 97 & $48.5 \%$ & 21 & $10.5 \%$ & 18 & $9.0 \%$ & 6 & $3.0 \%$ & 9 & $4.5 \%$ & $78.3 \%$ & 1 \\
\hline & Marbella kore & 56 & $28.0 \%$ & 86 & $43.0 \%$ & 13 & $6.5 \%$ & 24 & $12.0 \%$ & 4 & $2.0 \%$ & 17 & $8.5 \%$ & $75.6 \%$ & 2 \\
\hline & POP & 82 & $41.0 \%$ & 45 & $22.5 \%$ & 16 & $8.0 \%$ & 26 & $13.0 \%$ & 13 & $6.5 \%$ & 18 & $9.0 \%$ & $67.6 \%$ & 7 \\
\hline & Minino Red & 59 & $29.5 \%$ & 48 & $24.0 \%$ & 29 & $14.5 \%$ & 30 & $15.0 \%$ & 13 & $6.5 \%$ & 21 & $10.5 \%$ & $63.7 \%$ & 12 \\
\hline & Minino green & 74 & $37.0 \%$ & 49 & $24.5 \%$ & 14 & $7.0 \%$ & 29 & $14.5 \%$ & 11 & $5.5 \%$ & 23 & $11.5 \%$ & $66.7 \%$ & 8 \\
\hline & PiERPOT & 37 & $18.5 \%$ & 49 & $24.5 \%$ & 27 & $13.5 \%$ & 37 & $18.5 \%$ & 11 & $5.5 \%$ & 39 & $19.5 \%$ & $56.9 \%$ & 15 \\
\hline & Maxi apple & 36 & $18.0 \%$ & 48 & $24.0 \%$ & 37 & $18.5 \%$ & 35 & $17.5 \%$ & 12 & $6.0 \%$ & 32 & $16.0 \%$ & $57.5 \%$ & 14 \\
\hline & $\begin{array}{c}\text { Caramel of } \\
\text { Basetti }\end{array}$ & 78 & $39.0 \%$ & 34 & $17.0 \%$ & 31 & $15.5 \%$ & 28 & $14.0 \%$ & 16 & $8.0 \%$ & 13 & $6.5 \%$ & $64.4 \%$ & 10 \\
\hline & $\begin{array}{c}\text { Mickey and } \\
\text { Anos lollipop }\end{array}$ & 97 & $48.5 \%$ & 41 & $20.5 \%$ & 17 & $8.5 \%$ & 14 & $7.0 \%$ & 17 & $8.5 \%$ & 14 & $7.0 \%$ & $68.6 \%$ & 6 \\
\hline & $\begin{array}{l}\text { Mickey and } \\
\text { Anos sweets }\end{array}$ & 71 & $35.5 \%$ & 28 & $14.0 \%$ & 29 & $14.5 \%$ & 35 & $17.5 \%$ & 10 & $5.0 \%$ & 27 & $13.5 \%$ & $59.7 \%$ & 13 \\
\hline & Orange lollipop & 86 & $43.0 \%$ & 50 & $25.0 \%$ & 18 & $9.0 \%$ & 26 & $13.0 \%$ & 12 & $6.0 \%$ & 8 & $4.0 \%$ & $72.0 \%$ & 3 \\
\hline & Lemon sucker & 97 & $48.5 \%$ & 17 & $8.5 \%$ & 21 & $10.5 \%$ & 36 & $18.0 \%$ & 18 & $9.0 \%$ & 11 & $5.5 \%$ & $64.1 \%$ & 11 \\
\hline & SOna POP & 127 & $63.5 \%$ & 9 & $4.5 \%$ & 15 & $7.5 \%$ & 21 & $10.5 \%$ & 16 & $8.0 \%$ & 22 & $11.0 \%$ & $66.2 \%$ & 9 \\
\hline & $\begin{array}{c}\text { Laban Alwan } \\
\text { Core } \\
\end{array}$ & 91 & $45.5 \%$ & 52 & $26.0 \%$ & 25 & $12.5 \%$ & 9 & $4.5 \%$ & 15 & $7.5 \%$ & 8 & $4.0 \%$ & $71.6 \%$ & 4 \\
\hline & Jelly straw. & 87 & $43.5 \%$ & 47 & $23.5 \%$ & 26 & $13.0 \%$ & 18 & $9.0 \%$ & 13 & $6.5 \%$ & 9 & $4.5 \%$ & $70.2 \%$ & 5 \\
\hline & Juicy Cola & 33 & $16.5 \%$ & 3 & $1.5 \%$ & 17 & $8.5 \%$ & 11 & $5.5 \%$ & 15 & $7.5 \%$ & 121 & $60.5 \%$ & $22.9 \%$ & 16 \\
\hline \multicolumn{3}{|c|}{ Percent (\%) } & $36.25 \%$ & & $21.97 \%$ & & $11.13 \%$ & & $12.41 \%$ & & $6.31 \%$ & & $12.25 \%$ & & \\
\hline
\end{tabular}




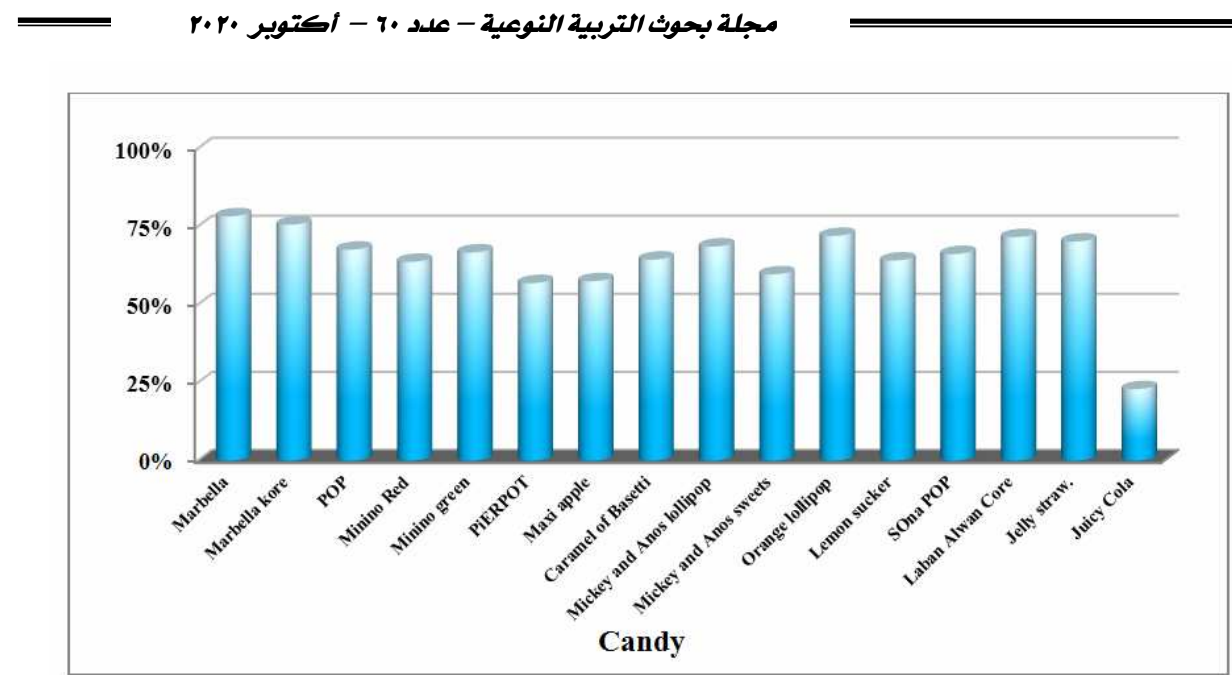

Fig (3) Relative distribution of children in the research

Sample, in terms of the number of times to eat Sweets

Data in Table (4) and Fig( 4)showed that relative distribution of children in the research sample in terms of the number of times to eat ice cream and Jelly.

Relative distribution of children in the research sample in terms of the number of times to eat ice -cream and Jelly. Relative distribution of children in the research sample in terms of the number of times to eat ice cream and Jelly. The variety of Viola water melon came in the most daily intake by $(77.3 \%)$ Followed by orange Jelly by (76.8\%)Then Strawberries Jelly by $(71.3 \%)$. These results are in agreement with those reported by Asfaq and Masud, (2002) showed that according the data published in many countries it is showed that food intoxications are increasing. They are observed that colored food products are the major source for food intoxication. Adding attractive colors can enhance the appetizing value of foods and beverages. Therefore most food manufacturers use many colors in their products including confectioneries, fruit drinks, soft drinks, jams and jellies, etc. 


\section{- Survey Study On some Artificial Colors Intake by Children in Damietta}

Table (4):Relative distribution of children in the research sample in terms of the number of times to eat ice-cream and Jelly.

\begin{tabular}{|c|c|c|c|c|c|c|c|c|c|c|c|c|c|c|c|}
\hline \multirow{3}{*}{ 官 } & \multirow{3}{*}{ Item } & \multicolumn{12}{|c|}{ Eating children's foods } & \multirow{3}{*}{ 巳 } & \multirow{3}{*}{ 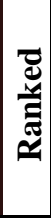 } \\
\hline & & \multicolumn{2}{|c|}{ Daily } & \multicolumn{2}{|c|}{$\begin{array}{l}\text { More than } \\
\text { once a day }\end{array}$} & \multicolumn{2}{|c|}{ Weekly } & \multicolumn{2}{|c|}{$\begin{array}{c}\text { More than } \\
\text { once a week }\end{array}$} & \multicolumn{2}{|c|}{ Monthly } & \multicolumn{2}{|c|}{$\begin{array}{c}\text { I don't eat } \\
\text { at all }\end{array}$} & & \\
\hline & & Cnt & $\%$ & Cnt & $\%$ & Cnt & $\%$ & Cnt & $\%$ & Cnt & $\%$ & Cnt & $\%$ & & \\
\hline \multirow{17}{*}{ 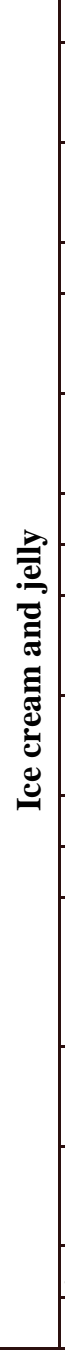 } & Ice cream MAga & 46 & $23.0 \%$ & 45 & $22.5 \%$ & 24 & $12.0 \%$ & 40 & $20.0 \%$ & 29 & $14.5 \%$ & 16 & $8.0 \%$ & $60.6 \%$ & 12 \\
\hline & $\begin{array}{c}\text { Chocolate Mega } \\
\text { Ice Cream }\end{array}$ & 108 & $54.0 \%$ & 27 & $13.5 \%$ & 16 & $8.0 \%$ & 22 & $11.0 \%$ & 15 & $7.5 \%$ & 12 & $6.0 \%$ & $68.0 \%$ & 5 \\
\hline & $\begin{array}{c}\text { Mango Ice } \\
\text { Cream } \\
\end{array}$ & 110 & $55.0 \%$ & 28 & $14.0 \%$ & 13 & $6.5 \%$ & 28 & $14.0 \%$ & 9 & $4.5 \%$ & 12 & $6.0 \%$ & $69.9 \%$ & 4 \\
\hline & Keima Okono & 99 & $49.5 \%$ & 29 & $14.5 \%$ & 16 & $8.0 \%$ & 30 & $15.0 \%$ & 13 & $6.5 \%$ & 13 & $6.5 \%$ & $67.6 \%$ & 6 \\
\hline & $\begin{array}{c}\text { Chocolate Ice } \\
\text { Cream } \\
\end{array}$ & 40 & $20.0 \%$ & 52 & $26.0 \%$ & 32 & $16.0 \%$ & 24 & $12.0 \%$ & 38 & $19.0 \%$ & 14 & $7.0 \%$ & $59.4 \%$ & 13 \\
\hline & $\begin{array}{c}\text { Granita Ice } \\
\text { Cream } \\
\end{array}$ & 90 & $45.0 \%$ & 41 & $20.5 \%$ & 24 & $12.0 \%$ & 6 & $3.0 \%$ & 16 & $8.0 \%$ & 23 & $11.5 \%$ & $64.7 \%$ & 9 \\
\hline & Super kima & 42 & $21.0 \%$ & 49 & $24.5 \%$ & 25 & $12.5 \%$ & 43 & $21.5 \%$ & 30 & $15.0 \%$ & 11 & $5.5 \%$ & $62.2 \%$ & 11 \\
\hline & Kimo Robio & 56 & $28.0 \%$ & 46 & $23.0 \%$ & 20 & $10.0 \%$ & 36 & $18.0 \%$ & 32 & $16.0 \%$ & 10 & $5.0 \%$ & $63.4 \%$ & 10 \\
\hline & $\begin{array}{c}\text { Kimo-conwalk } \\
\text { vanilla } \\
\end{array}$ & 101 & $50.5 \%$ & 24 & $12.0 \%$ & 22 & $11.0 \%$ & 28 & $14.0 \%$ & 20 & $10.0 \%$ & 5 & $2.5 \%$ & $67.2 \%$ & 7 \\
\hline & $\begin{array}{c}\text { Dolesica Ice } \\
\text { Cream }\end{array}$ & 44 & $22.0 \%$ & 43 & $21.5 \%$ & 29 & $14.5 \%$ & 23 & $11.5 \%$ & 49 & $24.5 \%$ & 12 & $6.0 \%$ & $56.7 \%$ & 14 \\
\hline & Viola ice cream & 149 & $74.5 \%$ & 26 & $13.0 \%$ & 6 & $3.0 \%$ & 10 & $5.0 \%$ & 5 & $2.5 \%$ & 4 & $2.0 \%$ & $77.3 \%$ & 1 \\
\hline & Dala Ice Cream & 67 & $33.5 \%$ & 32 & $16.0 \%$ & 14 & $7.0 \%$ & 16 & $8.0 \%$ & 50 & $25.0 \%$ & 21 & $10.5 \%$ & $55.4 \%$ & 15 \\
\hline & $\begin{array}{c}\text { Kimo kono, } \\
\text { vanilla and } \\
\text { chocolate }\end{array}$ & 58 & $29.0 \%$ & 52 & $26.0 \%$ & 21 & $10.5 \%$ & 35 & $17.5 \%$ & 25 & $12.5 \%$ & 9 & $4.5 \%$ & $66.4 \%$ & 8 \\
\hline & $\begin{array}{c}\text { Chinese ice } \\
\text { cream }\end{array}$ & 53 & $26.5 \%$ & 36 & $18.0 \%$ & 20 & $10.0 \%$ & 17 & $8.5 \%$ & 58 & $29.0 \%$ & 16 & $8.0 \%$ & $54.1 \%$ & 17 \\
\hline & $\begin{array}{c}\text { Shenboa Ice } \\
\text { Cream } \\
\end{array}$ & 36 & $18.0 \%$ & 46 & $23.0 \%$ & 34 & $17.0 \%$ & 19 & $9.5 \%$ & 46 & $23.0 \%$ & 19 & $9.5 \%$ & $54.5 \%$ & 16 \\
\hline & Jelly with orange & 152 & $76.0 \%$ & 22 & $11.0 \%$ & 5 & $2.5 \%$ & 11 & $5.5 \%$ & 7 & $3.5 \%$ & 3 & $1.5 \%$ & $76.8 \%$ & 2 \\
\hline & Strawberry jelly & 128 & $64.0 \%$ & 20 & $10.0 \%$ & 14 & $7.0 \%$ & 19 & $9.5 \%$ & 15 & $7.5 \%$ & 4 & $2.0 \%$ & $71.2 \%$ & 3 \\
\hline & Percent (\%) & & $40.56 \%$ & & $18.18 \%$ & & $9.85 \%$ & & $11.97 \%$ & & $13.44 \%$ & & $6.00 \%$ & & \\
\hline
\end{tabular}




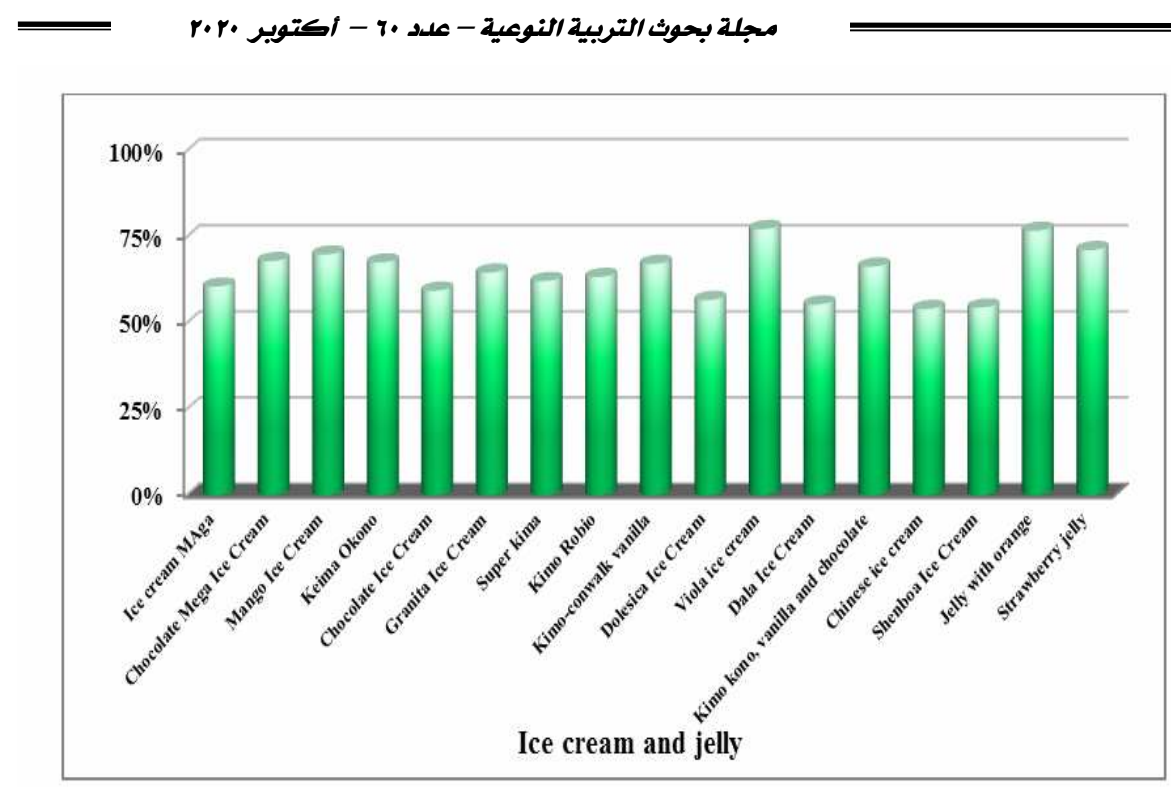

Fig (4) Relative distribution of children in the research

Sample in terms of the number of the times to eat ice-cream and Jelly

Data in Table 5 and Fig (5) showed that relative distribution of children for research sample in terms of the number of times.

\section{A set juices and drinks}

The results showed in Table (5) and Fig (5) Fruit Juice, and found that the percentage of consumed daily is $32 \%$, the rate of consuming it more than once a day is $9.5 \%$, the rate of consuming it more than once a day is $14.5 \%$, the rate of consuming it more than once a week is $26 \%$, the rate of consuming it more than once a week, and the rate of consumption $9 \%$ Never $9 \%$. 


\section{- Survey Study On some Artificial Colors Intake by Children in Damietta}

Table( 5 ): Shows The relative distribution of children for the research sample in terms of the number Of times consuming Juices and drinks.

\begin{tabular}{|c|c|c|c|c|c|c|c|c|c|c|c|c|c|c|c|}
\hline \multirow{3}{*}{ 官 } & \multirow{3}{*}{ Item } & \multicolumn{12}{|c|}{ Eating children's foods } & \multirow{3}{*}{ 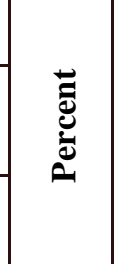 } & \multirow{3}{*}{ 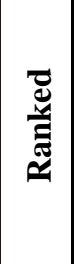 } \\
\hline & & \multicolumn{2}{|c|}{ Daily } & \multicolumn{2}{|c|}{$\begin{array}{l}\text { More than } \\
\text { once a day }\end{array}$} & \multicolumn{2}{|c|}{ Weekly } & \multicolumn{2}{|c|}{$\begin{array}{l}\text { More than } \\
\text { once a week }\end{array}$} & \multicolumn{2}{|c|}{ Monthly } & \multicolumn{2}{|c|}{$\begin{array}{c}\text { I don't eat } \\
\text { at all }\end{array}$} & & \\
\hline & & Cnt & $\%$ & Cnt & $\%$ & Cnt & $\%$ & Cnt & $\%$ & Cnt & $\%$ & Cnt & $\%$ & & \\
\hline \multirow{5}{*}{ 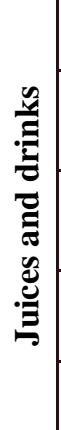 } & fruit juice & 64 & $32.0 \%$ & 19 & $9.5 \%$ & 29 & $14.5 \%$ & 52 & $26.0 \%$ & 18 & $9.0 \%$ & 18 & $9.0 \%$ & $58.3 \%$ & 4 \\
\hline & $\begin{array}{c}\text { Fanta green } \\
\text { apple }\end{array}$ & 68 & $34.0 \%$ & 25 & $12.5 \%$ & 24 & $12.0 \%$ & 50 & $25.0 \%$ & 20 & $10.0 \%$ & 13 & $6.5 \%$ & $61.5 \%$ & 3 \\
\hline & Strawberry & 63 & $31.5 \%$ & 28 & $14.0 \%$ & 28 & $14.0 \%$ & 40 & $20.0 \%$ & 15 & $7.5 \%$ & 26 & $13.0 \%$ & $58.3 \%$ & $\begin{array}{c}\text { Rep. } \\
4\end{array}$ \\
\hline & Loleta & 93 & $46.5 \%$ & 42 & $21.0 \%$ & 22 & $11.0 \%$ & 12 & $6.0 \%$ & 18 & $9.0 \%$ & 13 & $6.5 \%$ & $68.0 \%$ & 1 \\
\hline & UOGO & 87 & $43.5 \%$ & 41 & $20.5 \%$ & 25 & $12.5 \%$ & 18 & $9.0 \%$ & 8 & $4.0 \%$ & 21 & $10.5 \%$ & $66.5 \%$ & 2 \\
\hline \multicolumn{3}{|c|}{ Percent (\%) } & $37.50 \%$ & & $15.50 \%$ & & $12.80 \%$ & & $17.20 \%$ & & $7.90 \%$ & & $9.10 \%$ & & \\
\hline
\end{tabular}

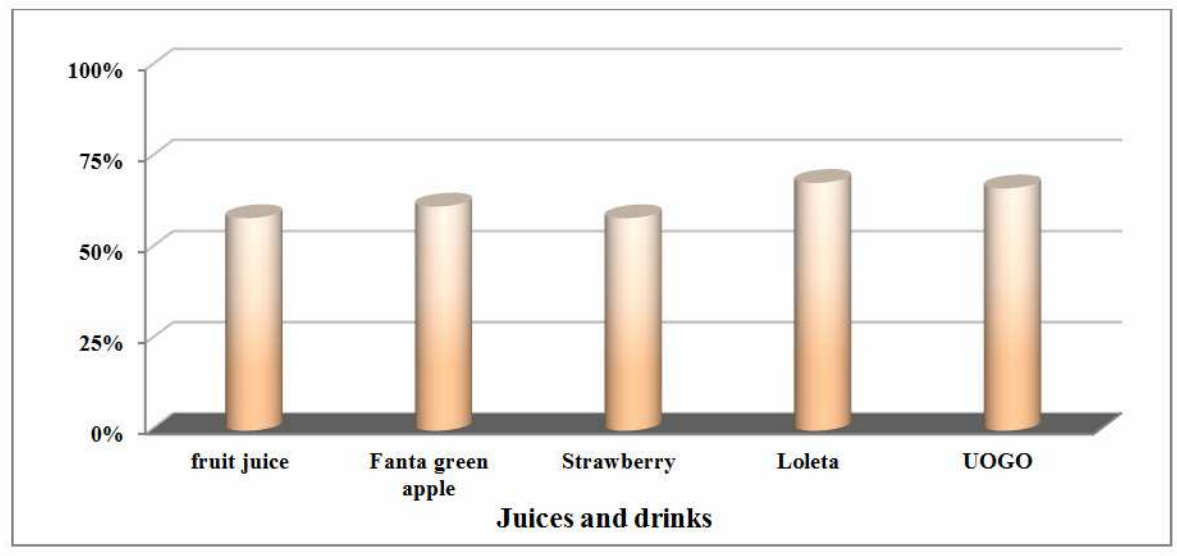

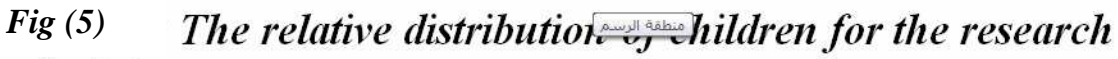

Sample in terms of the number of times consuming Juices and drinks. 
Data in Table (6) and Fig (6) and Fig (7) showed that relative distribution of children for the research sample in Terms of the number of times children eat foods.

In the present study it was noticed that The percentage of consuming the first group, which is Baked goods daily, is $38.50 \%$, the rate of consuming more than once a day is $16.64 \%$, the rate of consuming it more than once a day is $10.73 \%$, the rate of consuming it more than once in a week is $17.86 \%$, the rate of consuming it more than once in a week is $17.86 \%$, the rate of eating it more than once a week is $10.41 \%$ and the rate of consuming it absolutely $5.86 \%$

The percentage of consuming the third group, which is Ice cream daily and jelly, is $40.56 \%$, the rate of consuming more than once a day is $18.18 \%$, the rate of consuming it more than once a week is $9.85 \%$, the rate of consuming it more than once a week is $11.97 \%$, the rate of consuming it more than once in a week is $11.97 \%$, the rate of consuming it more than once a week is $13.44 \%$, and the percentage of eating it at all $6 \%$.

The percentage of consuming the fourth group, which is Juices and drinks daily, is $37.50 \%$ the rate of consuming more than once a day is $15.50 \%$ the rate of consuming it more than once a week is $12.80 \%$ the rate of consuming it more than once a week is $11.97 \%$, the rate of consuming it more than once in a week.17.20\%the rate of consuming it more than once a week is $7.90 \%$ and the percentage of eating it at all $9.10 \%$

The most delicious baked items came daily with a relative weight $64.53 \%$

Weight followed by a set of ice cream and Jelly with a relative $64.44 \%$ then a candy group with a relative weight $64.13 \%$

And finally a group of Juices and drinks with a relative weight $62.52 \%$ 


\section{- Survey Study On some Artificial Colors Intake by Children in Damietta}

Table ( 6 ): Shows the relative distribution of children for the research sample in Terms of the number of times children eat foods.

\begin{tabular}{|c|c|c|c|c|c|c|c|c|}
\hline \multirow[b]{2}{*}{ Group } & \multicolumn{6}{|c|}{ Eating children's foods } & \multirow[b]{2}{*}{$(\%)$} & \multirow[b]{2}{*}{ 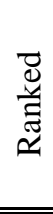 } \\
\hline & Daily & $\begin{array}{l}\text { More than } \\
\text { once a day }\end{array}$ & Weekly & $\begin{array}{c}\text { More than } \\
\text { once a } \\
\text { week }\end{array}$ & Monthly & $\begin{array}{c}\text { I don't eat } \\
\text { at all }\end{array}$ & & \\
\hline Baked goods & $38.50 \%$ & $16.64 \%$ & $10.73 \%$ & $17.86 \%$ & $10.41 \%$ & $5.86 \%$ & $64.53 \%$ & 1 \\
\hline Candy & $36.25 \%$ & $21.97 \%$ & $11.13 \%$ & $12.41 \%$ & $6.31 \%$ & $12.25 \%$ & $64.13 \%$ & 3 \\
\hline Ice cream and jelly & $40.56 \%$ & $18.18 \%$ & $9.85 \%$ & $11.97 \%$ & $13.44 \%$ & $6.00 \%$ & $64.44 \%$ & 2 \\
\hline Juices and drinks & $37.50 \%$ & $15.50 \%$ & $12.80 \%$ & $17.20 \%$ & $7.90 \%$ & $9.10 \%$ & $62.52 \%$ & 4 \\
\hline
\end{tabular}

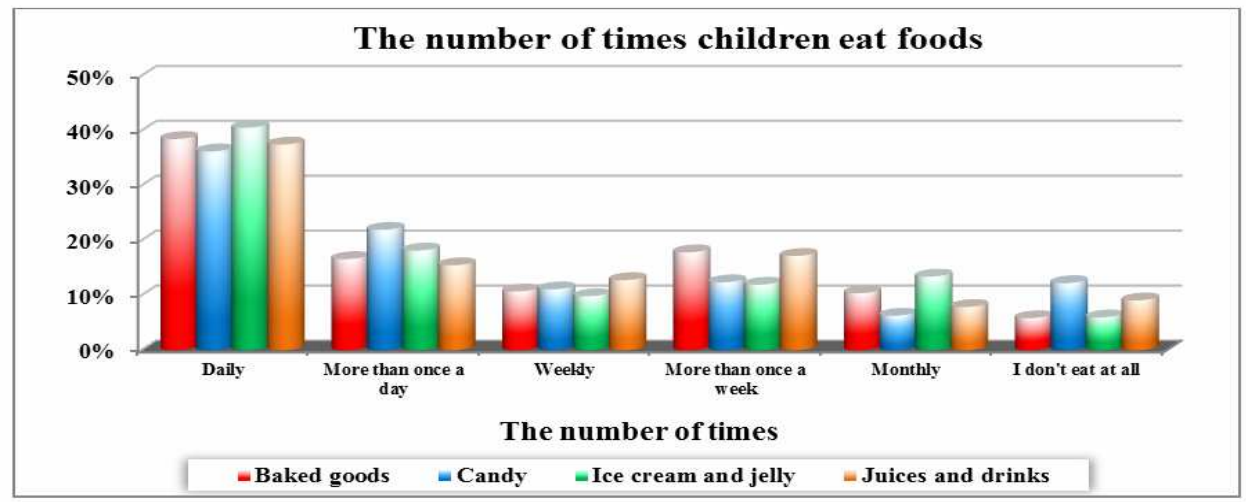

Fig (6) :The relative distribution of children for the research

Sample in terms of the number of times children eat foods 


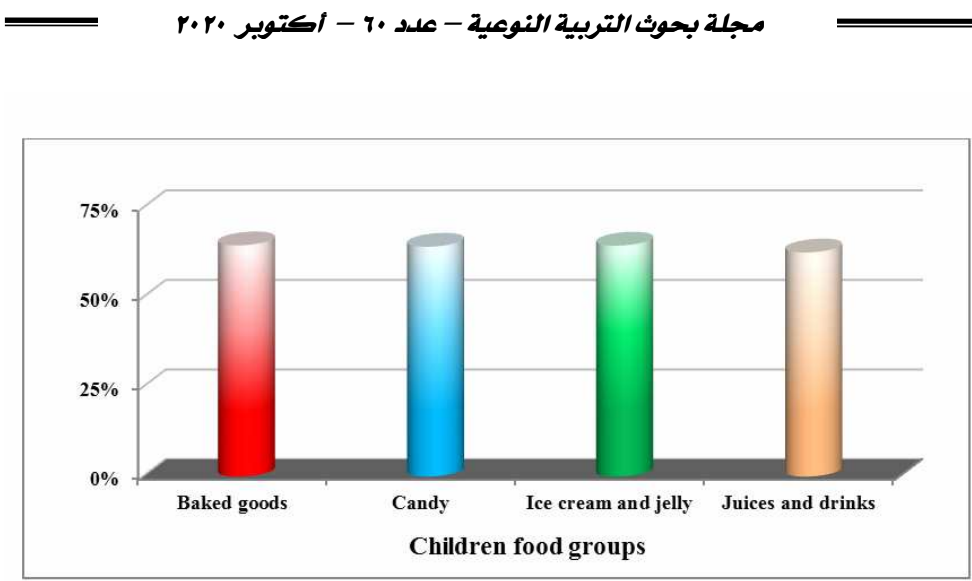

Fig (7) : weight distribution of children for the research Sample in terms of the times eat group children foods.

\section{Results of tatrazine analysis (E 102)}

\section{Results of E 102 analysis using supercritical HPLC (Jasco)}

Data in Table (7) showed that the results of analysis for the concentratioins of tatrazine (E102) in the foods that the children ate

From Table (7) it becomes clear that the average concentration of tartarzine (E 102) in the foods that the children ate (the research sample) was less than the international permissible $(7.5 \mathrm{mg}$ per kilogram of the human body)

This disagreed with the study of pratima and sudershan,( 2008) the present study was an attempt to assess the risk of selected population to synthetic food colors. Children had high intakes of cultured solid (25? $465 \mathrm{~g}$ day-1) and liquid foods (25? $840 \mathrm{ml}$ day-1). The study showed the predominant consumption of two colors such as tartrazine and sunset yellow mainly from sweetmeats, beverages and fast foods The intakes of colors like tartrazine, erythrosine and sunset yellow were high among children due to ingestion of foods containing high concentrations of colors (9.45 and 4.0 $\mathrm{mg}$ ). The study emphasized the need to evaluate the risk of the population to colors on a long-term basis. Also this disagreed with the study of Sharma et al ., (2009) showed that the Tartrazine is a water soluble synthetic lemon- 
yellow azo dye used as a food colorant with an acceptable daily intake (ADI) of $0-7.5 \mathrm{mg} / \mathrm{kg}$ body weight

Also this disagreed with the study of Zigmas, (2016)stated that tartrazine is a synthetic orange powder or granules soluble in water, consisting of a minimum of $85 \%$ "total coloring matters content" calculated as sodium salt. Tartrazine in feeding stuffs and water. Therefore the EURL cannot evaluate nor recommend any method for official control to determine Tartrazine in feeding stuffs and water

Table (7): shows the results of the analysis for the concentrations of tatarzine (E 102 ) in the foods that the children ate (the research sample).

\begin{tabular}{|c|c|c|c|c|c|c|c|}
\hline sample & $\begin{array}{c}\text { Package } \\
\text { Weight }(\mathrm{g})\end{array}$ & $\begin{array}{c}\text { Average } \\
\text { daily intake } \\
\text { (g) }\end{array}$ & $\begin{array}{c}\text { Average } \\
\text { daily intake } \\
\text { (g) }\end{array}$ & $\begin{array}{c}\text { The } \\
\text { concentration of } \\
\text { the substance (E } \\
\text { 102) in the } \\
\text { package }\end{array}$ & $\begin{array}{c}\text { Focus on } \\
\text { the material } \\
\text { covered }\end{array}$ & $\begin{array}{c}\text { Average } \\
\text { weight of } \\
\text { children }(\mathrm{kg})\end{array}$ & $\begin{array}{c}\text { Concentratio } \\
\mathrm{n} \text { rate }(\mathrm{mg} / \\
\mathrm{kg} \mathrm{bw})\end{array}$ \\
\hline loleta & 40 & 15.45 & 20.60 & 33.59 & 692 & \multirow{5}{*}{14.15} & 0.05 \\
\hline U Go & 350 & 7.08 & 82.60 & 13.21 & 1091 & & 0.08 \\
\hline Jelly straw. & 75 & 3.97 & 9.93 & 14.71 & 1.46 & & 0.10 \\
\hline maxi apple & 350 & 4.15 & 48.42 & 19.23 & 931 & & 0.07 \\
\hline jelly orange & 75 & 6.28 & 15.70 & 17.02 & 2.67 & & 0.19 \\
\hline
\end{tabular}

\section{Results of E 122 analysis using supercritical HPLC (Jasco)}

From Table (8) it becomes clear that the average concentration of carmosine (E 122) in the foods that the children ate (the research sample) was less than the international permissible (4 milligrams per kilogram of the human body). From Table (8) it becomes clear that the average concentration of carmosine (E 122) in the foods that the children ate (the research sample) was less than the international permissible (4 milligrams per kilogram of the human body).

This disagreed with the study of (Karen et al., 2006; Martin, 2007 )

Also, Synthetic food additive colors have been introduced in our food in order to give attractive colors to it. It has been noticed, however, that most of the applied synthetic food colors have properties similar to the 
مجلة بحوث التربية النوعية - عدد •r.r. r. r أكتوير

Synthetic food colors have properties similar to the mutagenic chemicals. Evidences have accumulated in the last years to indicate that a large number of synthetic food additives are capable of inducing genetic diseases to human.

\begin{tabular}{|c|c|c|c|c|c|c|c||}
\hline \hline sample & $\begin{array}{c}\text { Package } \\
\text { Weight }(\mathrm{g})\end{array}$ & $\begin{array}{c}\text { Average Intake } \\
\text { (during the period) } \\
\text { (Package) }\end{array}$ & $\begin{array}{c}\text { Average } \\
\text { daily intake } \\
(\mathrm{g})\end{array}$ & $\begin{array}{c}\text { The } \\
\text { concentration of } \\
\text { the substance }(\mathrm{E}) \\
\text { 102) in the } \\
\text { package }\end{array}$ & $\begin{array}{c}\text { Focus on the } \\
\text { material } \\
\text { covered }\end{array}$ & $\begin{array}{c}\text { Average } \\
\text { weight of } \\
\text { children } \\
(\mathrm{kg})\end{array}$ & $\begin{array}{c}\text { Concentratio } \\
\mathrm{n} \text { rate }(\mathrm{mg} / \\
\mathrm{kg} \mathrm{bw})\end{array}$ \\
\hline \hline loleta & 40 & 18.2 & 24.27 & 32.93 & 799.10 & \multirow{2}{*}{14.26} & 0.06 \\
\hline Jelly & 15 & 16.04 & 8.02 & 5.2 & 0.42 & & 0.03 \\
\hline
\end{tabular}

Data presented in Table (9) figure (8) and figure(9) shows the level averages and standard deviations of hemoglobin level Before and after eating children's food.

The table showed the table showed that there was an increase in the rate of the shows the level averages and standard deviations of hemoglobin level before and after eating children's food

Results also showed that there was an increase in the rate of the hemoglobin Improvement rate after taking twice (-7.11\%) Improvement rate after taking three times $(-13.70 \%)$ $13.64 \%)$

The rate of improvement after eating more than three times (-

Table (9) :The level averages and standard deviations of hemoglobin level Before and after eating children's food.

\begin{tabular}{|c|c|c|c|c|c|}
\hline \multirow{3}{*}{ Count times eating } & \multicolumn{5}{|c|}{ Hemoglobin level } \\
\hline & \multicolumn{2}{|c|}{ Before eating } & \multicolumn{2}{|c|}{ After eating } & \multirow{2}{*}{$\begin{array}{c}\text { Improvement }(\%) \\
\text { ratio }\end{array}$} \\
\hline & Mean & SD & Mean & SD & \\
\hline Twice a day & 9.74 & 0.82 & 9.05 & 0.88 & $-7.11 \%$ \\
\hline Three times a day & 9.23 & 1.26 & 7.97 & 1.27 & $-13.70 \%$ \\
\hline More than three times & 8.78 & 1.22 & 7.58 & 1.08 & $-13.64 \%$ \\
\hline
\end{tabular}




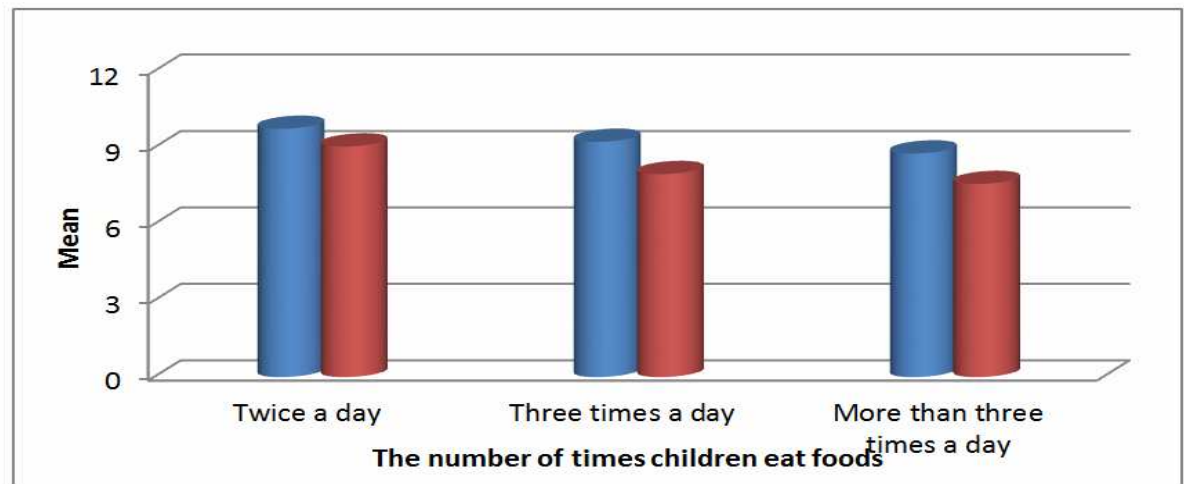

Fig (8) the percentage of improvement in the level of Hemoglobin before and after eating children's foods .

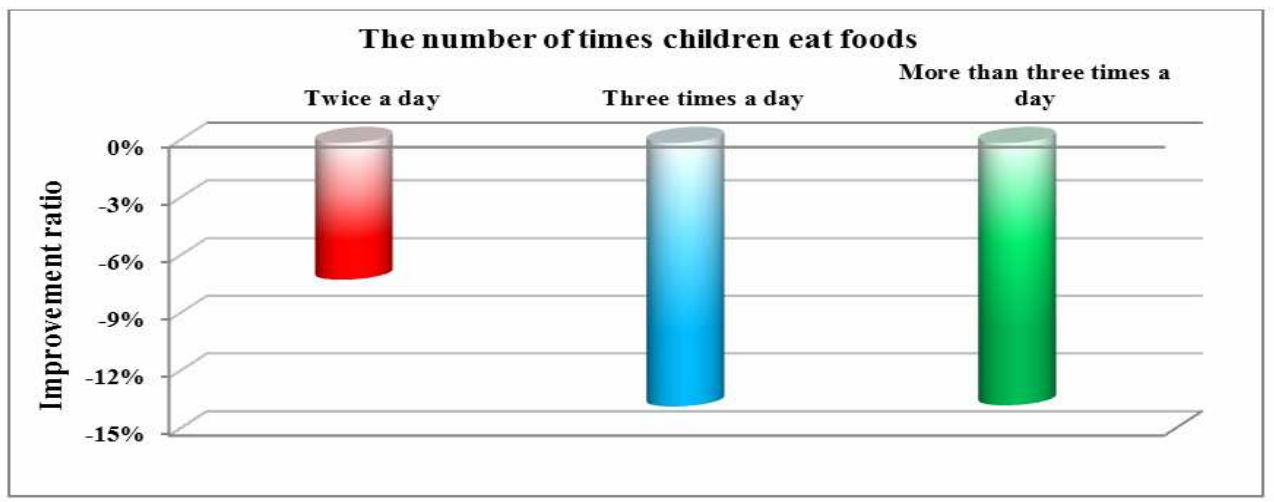

Fig (9) : the percentage of improvement in the level of Hemoglobin before and after eating children's foods.

\section{REFERENCES}

- Amin, K.A.; Abdel-Hameid, H .and Abd Elsattar, A. H. (2010):Effect of food azo dyes tartrazine and carmoisine on biochemical parameters related to renal, hepatic function and oxidative stress biomarkers in young male rats. Food and Chemical Toxicology, 48:2994-2999.

- Ashfaq N. and Masud T.( 2002) : ' Surveillance on Artificial Colours in Different Ready to Eat Foods'. Pakistan Journal of Nutrition ,1 (5): 223-225 
- Batada, A .and Jacobson ,M.F.(2016): Prevalence of Artificial Food Colors in Grocery Store Products Marketed to Children . Clin Pediatr(Phila),55(12):11139. oi:10.1177/0009922816651621.

- Elena ,S. (2013): Healthy Eating for Children Ages 2 to 5 Years Old: A Guide for Parents and Caregivers CHILDHOOD OBESITY Volume 9, Number 3Mary Ann Liebert, Inc.DOI: 10.1089

- El-Sheikh ,A.H . and Al-Degs, Y.S. (2013): Spectrophotometric determination of food dyes in soft drinks by second order multivariate calibration of the absorbance spectra-pH data matrices. Dyes and Pigments, 97 (2): 330-339.

- Ghoreishi, S. M.; Behpour, M.and Golestaneh, M. (2012): Simultaneous determination of Sunset yellow and Tartrazine in soft drinks using gold nanoparticles carbon paste electrode Food Chemistry-132,637-641.

- Jelliffe, D. B. (1966): Assessment of Nutritional Ntatus of Community who Monograph Series, No. 53, Geneva

- Kamal, A.A. and Fawzia, S. AL. (2018): Toxicological and safety assessment of tartrazine as asynthetic food additive on healthbiomarkers: A review Received 25 October,2017; Accepted 15 January, 2018.

- Karen, L.; W. G. Mclean; D. P. Williams and C. V. Howard , (2006): Synergistic interactions between commonly used food additives in a developmental neurotoxicity test Tox. Sci., 46: 177-184.

- Latifa ,K.I.; Amina, E.;Jehan, S. and Ahmed, S .(2017): Tartrazine induces structural and functional aberrations and genotoxic effects in vivo Submitted

- Laurian ,V.; Dana,M.; Cobzac ,S.C. and Filip ,L.(2014): Development and Validation of HPLC -UV method for determination of synthetic food colorants .September 2014. Revue Roumaine de chimie 59(9):719-725.

- Lee,R.D. and Nieman ,D.C.(1996):Nutritional Assessment ,Mobsy - year book, inc .Iouis Missouri .

- Martin, H. (2007): Soft drinks cause degenerative DNA diseases. http://news. indep endent.Co.uk/ health article.

- Pratima, R. and Sudershan, R.V. (2008): Risk assessment of synthetic food colours: a case study in Hyderabad, India ,Vol. 1, Issue 1, pp. 68-87 
- Salama, M. S. (2016): “The use of GST- $\mu$ Gene and Isoenzymes as Biomarkers to Evaluate the Mutagenicity and Hepatic Carcinogenicity in the Mouse by Carmoisine E122 ' Journal of Medicine and Medical Sciences,Vol.4 ,No.6,2016.

- Sawaya ,W.; Husain, A.; Al-Otaibi ,J.; Al-Foudari.and M, Hajji A. (2008): Colour additive levels in foodstuffs commonly consumed by children in Kuwait. Food Control, 19(1): 98-105

- Shafiquzzaman ,S and Sharifudin,M.D.Sh .(2016): Sensitive Determination of Tartrazine (E 102) Based on Chitosan/Nanoparticles/MWCNTs Modified Gold Electrode in Food and Beverage Products Received: 20 March 2016

- Yamjala, K.; Nainar ,M. Sand Ramisetti, N.R .(2016) : Methods for the analysis of azo dyes employed in food industry: A review. Food Chem., 192: 813-824.

- Zigmas,A.(2016): Development and Validation of HPLC Method for the Simultaneous Determination of Five Food Additives and Caffeine in Soft Drinks Article in International Journal of Analytical Chemistry · February 2016 


\section{الدراسة المسحية للألوان الاصطناعية الاضافة}

\section{لبعض أطعمة الأطفال المتناولة فى محافظة دمياط}

حامد محمد عمارة* - غادة مسعد الصعيدى* - منح أحمد شهيب

\section{الالذص العربي}

الغذاء ضروري لنمو الأطفال وتطورهم بشكل صحيح ، والاستهلاك المفرط للألوان

الاصطناعية ِِّ أغذية الأطفال هو مشكلة صحية خطيرة لها تأثير سلبي على نهو الأطفال وصحتهم. الهدف من هذه الدراسة هو تقييم مسح للألوان الصناعية ِِّ أغذية الأطفال بمحافظة

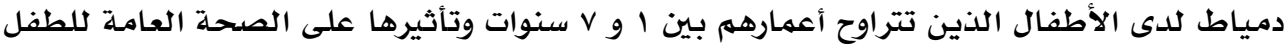

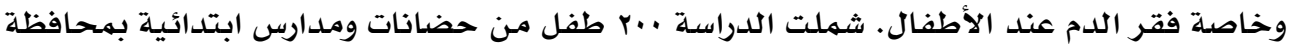

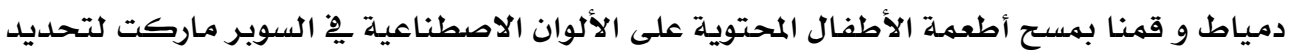

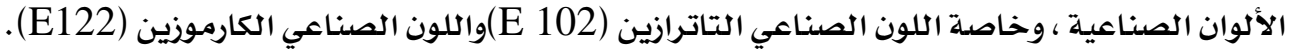

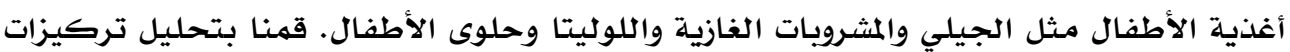

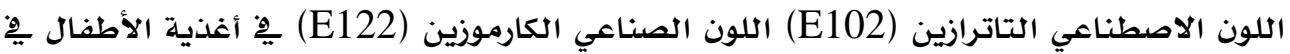

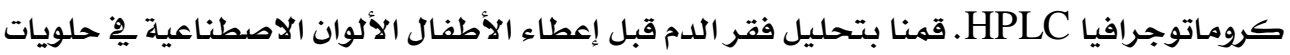

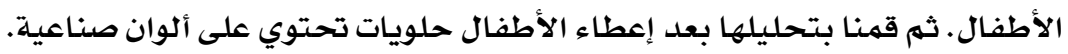
أظهرت النتائج أن الأطفال يِّن سن ثلاث سنوات تناولوا المزيد من أغذية الأطفال المحتوية

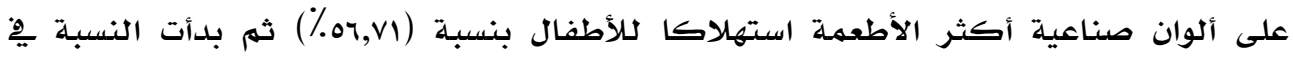

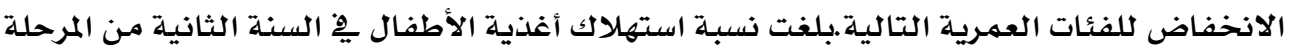

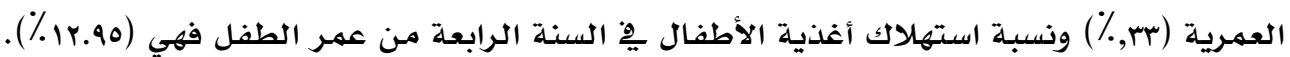

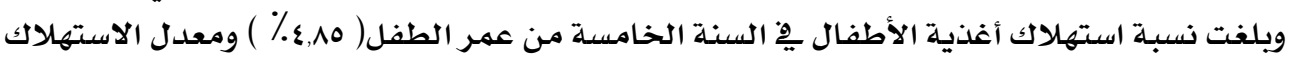

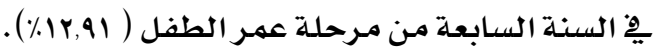
أظهرت النتائج أن نسبة تناول حلويات الأطفال يِ عينات مختلفة من التارتارازين (E102)

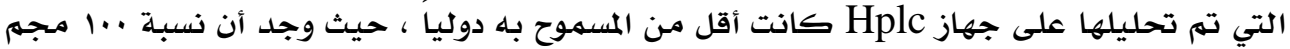

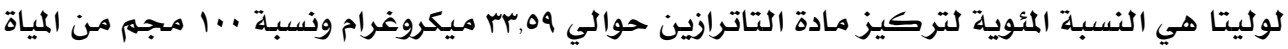

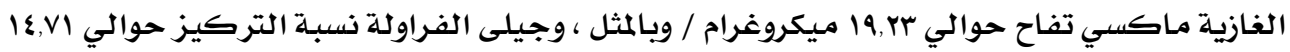

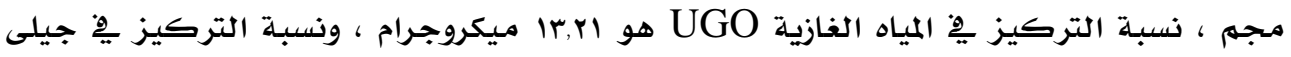


- Survey Study On some Artificial Colors Intake by Children in Damietta

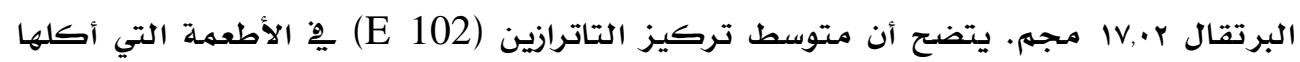

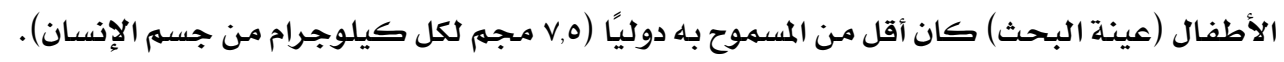

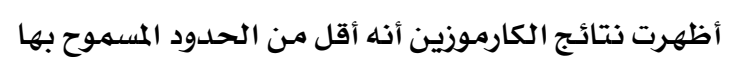

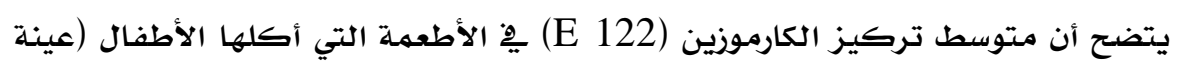
البحث) كان أقل من المسموح به دوليًا ( ( ملليغرام لكل كيلوغرام من جسمه الإنسان).

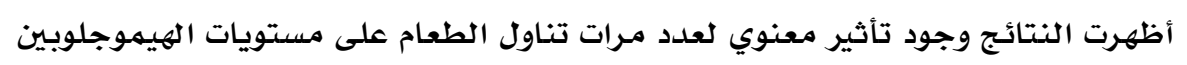

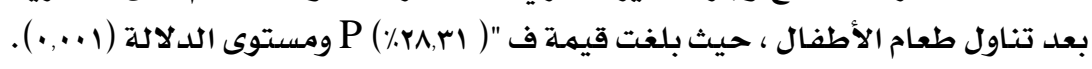
ممما يدل على وجود فروق ذات دلالة احصائية بين عدد المتناول وهذا ادى الى ارتفاع نسبة فقر الدم بين اطفال عينة البحث بعد تناول طعام الاطفال.

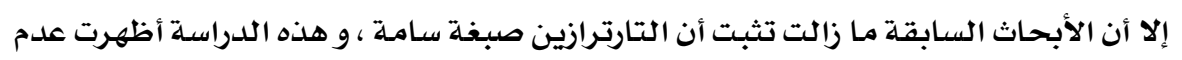

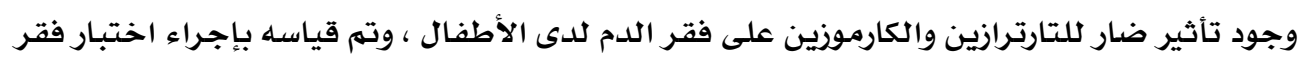

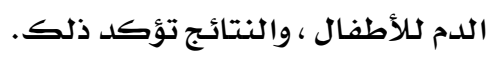
الكلمات المفتاحية : ألوان اصطناعية. التارترازين. الكارموزين. فقر دم 